\title{
Effect of the surface treatment of plain carbon fiber posts on the retention of the composite core: an in vitro evaluation
}

\section{Efeito do tratamento superficial de pinos de fibra de carbono lisos na retenção da resina de preenchimento: uma avaliação in vitro}

\author{
Adriana Ferreira QUINTAS* \\ Marco Antonio BOTTINO** \\ Maximiliano Piero NEISSER ${ }^{* *}$ \\ Maria Auxiliadora Junho de ARAÚJO***
}

\begin{abstract}
QUINTAS, A. F.; BOTTINO, M. A.; NEISSER, M. P.; ARAÚJO, M. A. J. de. Effect of the surface treatment of plain carbon fiber posts on the retention of the composite core: an in vitro evaluation. Pesqui Odontol Bras, v. 15, n. 1, p. 64-69, jan./mar. 2001.
\end{abstract}

\begin{abstract}
This study aims to evaluate the role of surface treatments performed on plain carbon fiber posts, in relation to serrated carbon fiber posts, in the retention of the composite core. Fifty carbon fiber posts received surface treatments in order to verify their influence on the retention of the core material. An acrylic resin mold was developed in order to precisely fit the post, leaving a machined space to accommodate a self-curing composite resin. After the surface treatment, a primer was applied on the coronal portion of all posts, which were then dried. They were fitted to the mold and received a $3 \mathrm{~mm}$ composite core. All specimens were thermocycled and then stored in distilled water for a week. Tension test was performed at a speed of $0.5 \mathrm{~mm} / \mathrm{min}$ until there was lack of adhesion or fracture of the core. The conclusions were: a) the values of retention related to aluminum oxide spray (group A), depth cutter diamond burs (group C) and posts with machined coronal portion (group D) were comparable to those of serrated posts (group E), although no statistically significant difference between these groups was found; b) the mean values of core retention in group B (medium grit diamond burs) were statistically lower than those of other groups.
\end{abstract}

UNITERMS: Composite resins; Denture retention; Pre-fabricated post.

\section{INTRODUCTION}

Over the past few years, improvements in dental materials have led to a decrease in the utilization of metal, enhanced aesthetics and good mechanical properties. However, researches have focused on restorative materials, with almost no concern about post and core materials. Endodontic treatment techniques have also been developed, with more predictable results. Consequently, endodontically treated teeth have their longevity increased. Despite all modern restorative materials, there are still a lot of controversies about the need for intraradicular retention and the type of coronal reconstruction ${ }^{2,16,19,20,26,29}$. SORENSEN; MARTINOFF ${ }^{28}$ (1984) stated that there is no root reinforcement related to the placement of a post; they have also pointed out the importance of coronal reconstruction in endodontically treated teeth located in the posterior region. VIRE ${ }^{31}$ (1991) evaluated the possible causes of failure in 116 endodontically treated teeth, and concluded that $59.4 \%$ of them failed for prosthetic reasons, all related to the post.

Many authors agree that the placement of posts is directly related to the need for a retention and resistance form $^{1,2,13,17,21}$. The retention and resistance form depends directly on the amount of sound tooth structure, tooth position, restorative choice and occlusal relationship.

Although metal-free restorations are aimed at in many recent studies, most posts used are still metallic. Many investigations have been carried out in order to find out about the possible effects of corrosion products and also to comprehend the behavior of various post materials inside the root canal, especially their modulus of elasticity.

* Ph.D Student, UNESP, São José dos Campos;

** Associate Professors; *** Chairman - Dental Materials and Prosthodontics Department, UNESP, São José dos Campos. 
QUINTAS, A. F.; BOTTINO, M. A.; NEISSER, M. P.; ARAÚJO, M. A. J. de. Effect of the surface treatment of plain carbon fiber posts on the retention of the composite core: an in vitro evaluation. Pesqui Odontol Bras, v. 15, n. 1, p. 64-69, jan./mar. 2001.

DURET et al. ${ }^{5}$ affirmed that the ideal restoration for endodontically treated teeth should have a shape identical to that of the root canal, the same mechanical properties as dentin and effective adhesion to the tooth. Carbon fiber posts were introduced due to their better mechanical properties in relation to metallic posts: their modulus of elasticity is closer to that of dentin ${ }^{5}$ and they have elevated resistance to fatigue ${ }^{7}$. Maybe these properties are responsible for the occurrence of more retrievable fractures related to carbon fiber posts when compared with pre-fabricated posts and cast posts in other studies ${ }^{8,12,13,22,27,30}$. Metallic posts have a modulus of elasticity that can be ten times grater than that of dentin ${ }^{7}$, resulting in greater tension in the root structure ${ }^{6,32}$. There is also a difference when comparing cast posts with posts and cores: according to YAMAN; THORSTEINSSON ${ }^{32}$ (1992), cast posts cause greater tension in the apical portion, whereas posts and cores, in the cervical region. Perhaps this fact can explain the greater number of failures with posts and cores in periodontally compromised teeth. Fatigue is a disadvantage in metallic posts when compared with carbon-fiber posts; the high percentage of fibers probably leds to incomplete fractures in these posts ${ }^{13}$.

Metal-free restorations are an aim in current dentistry, because of aesthetics and the absence of corrosion products ${ }^{2,9,22,23,25}$. HORNBROOK; HASTINGS $^{10}$ (1995) pointed out that cast posts and amalgam cores can be apparent through the root surface, thus they indicate tooth-colored cores for better aesthetic results. Regardless of the presence of a luting agent, avoidance of different metal alloys for posts and crowns is recommended by DEUTSCH et al. ${ }^{4}$ (1983). The chemical stability presented by carbon fiber posts is advantageous when compared with that of metallic posts ${ }^{9}$.

Posts should fit dentin apically; the high percentage of unidirectional carbon fibers (64\%) ensures good resistance to fatigue ${ }^{8}$. According to PURTON; LOVE ${ }^{23}$ (1996), the main advantages of carbon fiber posts are: high resistance to fatigue, resistance to corrosion and chemical compatibility with Bis-GMA. FREEDMAN ${ }^{7}$ (1996) states that carbon fiber posts have less transmission of stress when compared with titanium posts (about 63\%) and nickel-chromium posts (about 33\%). ISIDOR et al. ${ }^{12}$ (1996) applied intermittent load to teeth restored in three ways: carbon fiber posts and resin cement, Para-Posts and cast posts and zinc-phosphate cements; while $85 \%$ of the Para-Posts and
$100 \%$ of the cast posts failed against tensile strength, no carbon fiber post failed. Therefore, carbon fiber posts seem to be a good alternative to metallic posts and their presumed compatibility with composite resins would avoid corrosion products. Some studies ${ }^{8,12,18,27}$ concluded that the application of force caused less damage to the structure of teeth restored with carbon fiber posts when compared with those restored with metallic posts; SIDOLI et al. ${ }^{27}$ (1997) affirmed that there were more retrievable fractures with carbon fiber posts than with other posts. KING; SETCHELL ${ }^{13}$ (1990) pointed out the ease to remove them when endodontic retreatment is necessary.

Some investigations ${ }^{12,24}$ affirmed that the main problem with carbon fiber posts is the lack of adhesion to the core material. In order to solve this problem, manufacturers have introduced a serrated version. This version gained retention to the core while lost rigidity; this mechanical property of the serrated version is now closer to that of metallic posts but smaller than that of plain carbon fiber posts $^{15}$.

\section{MATERIALS AND METHODS}

Fifty carbon fiber posts (C-Post, \#3, BISCO, USA) were divided into five groups. Four groups contained plain posts that received modifications in the coronal portion before the placement of the core. Surface alterations were performed as follows: Group A - sandblasting; Group B - medium grit diamond bur; Group C - diamond burs used to determine the depth for laminate veneers (depth cutter); Group D - change of the head form. The last group (Group E) consisted of posts serrated by the manufacturer.

In Group A, sandblasting (with $50 \mu \mathrm{m}$ aluminum oxide) was carried out at a distance of $1 \mathrm{~mm}$, over a length of $3 \mathrm{~mm}$, on the coronal portion. Posts from Group B also had a length of $3 \mathrm{~mm}$ prepared with a medium grit diamond bur (Diamond Burs, number 315, Moyco, USA) in a direction parallel to their long axis; each bur was discarded after being used in one specimen. Group $\mathrm{C}$ received the same preparation with a depth cutter (Diamond Series, number S4, Moyco, USA); each bur was discarded after a single use. Group $D$ had their head machined as shown in Figure 1.

All posts received a double coat of Primer B (All-Bond, BISCO, USA) and were dried. A machined acrylic resin mold was developed and divided in two halves, where a \#3 C-Post fitted exactly (Figure 2); at the coronal end, a $3 \mathrm{~mm}$ space 
QUINTAS, A. F.; BOTTINO, M. A.; NEISSER, M. P.; ARAÚJO, M. A. J. de. Effect of the surface treatment of plain carbon fiber posts on the retention of the composite core: an in vitro evaluation. Pesqui Odontol Bras, v. 15, n. 1, p. 64-69, jan./mar. 2001.

was created in order to receive a composite resin core. A fine brush with a thin layer of solid Vaseline lubricated the coronal end before the placement of the core.

Then, a composite resin especially developed for core build-up (Core-Flo, BISCO, USA) was mixed as recommended by the manufacturer and then inserted in the 3-millimeter space. The post was then placed and both halves of the mold were screwed and kept under pressure; according to DURET et al. ${ }^{6}$ (1990) it is essential to push the composite material with some pressure into the microscopic retentions of the post, in order to link it with the matrix of the carbon fiber post. The composite resin that exceeded the capacity of the mold was removed with a spatula before setting. Any remaining excess of composite was trimmed with abrasive paper discs (Mooreplastics, garnet fine, Moore) placed in a handpiece mandrel.

The samples were thermocycled $(600$ cycles, 30 seconds, $5^{\circ} \mathrm{C}$ and $55^{\circ} \mathrm{C}$ ) and then kept in distilled water for one week.

The specimens were submitted to tension test in an Instron machine (model 4,301). A mandrel was adapted to the Instron machine and a metallic frame was developed in order to transmit the force exactly in the long axis of the samples (Figure 3), at a crosshead speed of $0.5 \mathrm{~mm} / \mathrm{min}$. The test was stopped when there was lack of adhesion or fracture of the core.

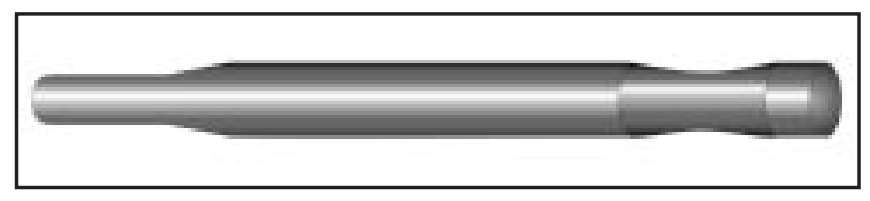

FIGURE 1 - Machined carbon fiber post.

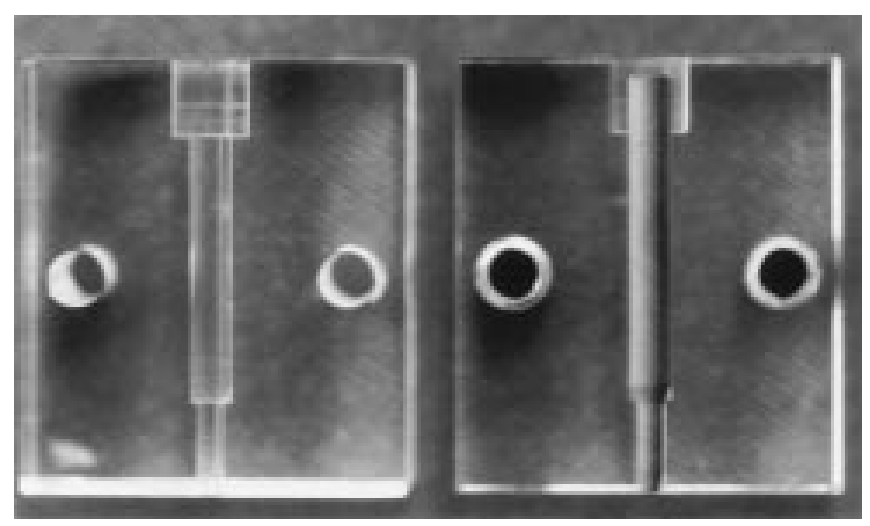

FIGURE 2 - Machined acrylic resin mold containing a carbon fiber post.

\section{RESULTS}

The data were submitted to a test of analysis of variance (ANOVA), with a confidence interval of $5 \%$. There was statistical difference between the groups at a level of $5 \%$. The Tukey comparison test demonstrated statistically significant difference between Group B and the other groups. There was no statistically significant difference related to the retention of the core between Groups A, C, D (treated plain posts) and E (serrated posts). Graphic 1 presents the mean values for all experimental conditions.

Regarding the type of failure, there was also a visual difference between the groups: the samples from Group B presented only dislodgment of the core, which was a completely different result from those of the other Groups. In $80 \%$ of the specimens from Group A, there was dislodgment of the core with partial or total fracture of the composite resin. In Groups $\mathrm{C}, \mathrm{D}$ and $\mathrm{E}$ there was core fracture in all specimens (Figure 4).

\section{DISCUSSION}

As stated by LOVE; PURTON ${ }^{15}(1996)$, plain carbon posts are mechanically superior to serrated ones, because of their greater rigidity. In spite of that, smaller adhesion to the core compromises the retention and resistance form that retains the crown. The results of this study concluded that the macroscopic retention encountered in Groups C,

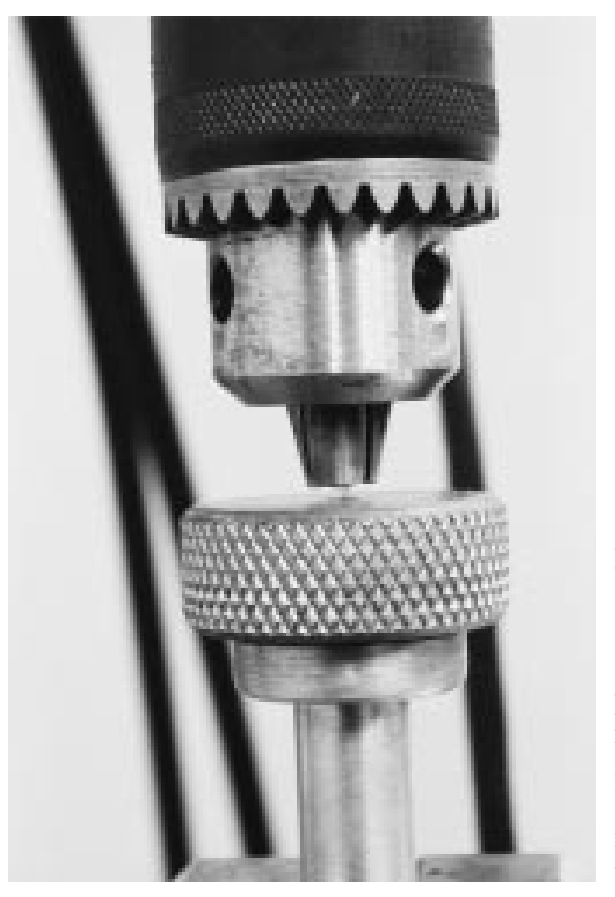

FIGURE 3

Metallic frame containing a carbon fiber post positioned in a mandrel adapted to the Instron machine for tensile testing. 
QUINTAS, A. F.; BOTTINO, M. A.; NEISSER, M. P.; ARAÚJO, M. A. J. de. Effect of the surface treatment of plain carbon fiber posts on the retention of the composite core: an in vitro evaluation. Pesqui Odontol Bras, v. 15, n. 1, p. 64-69, jan./mar. 2001.

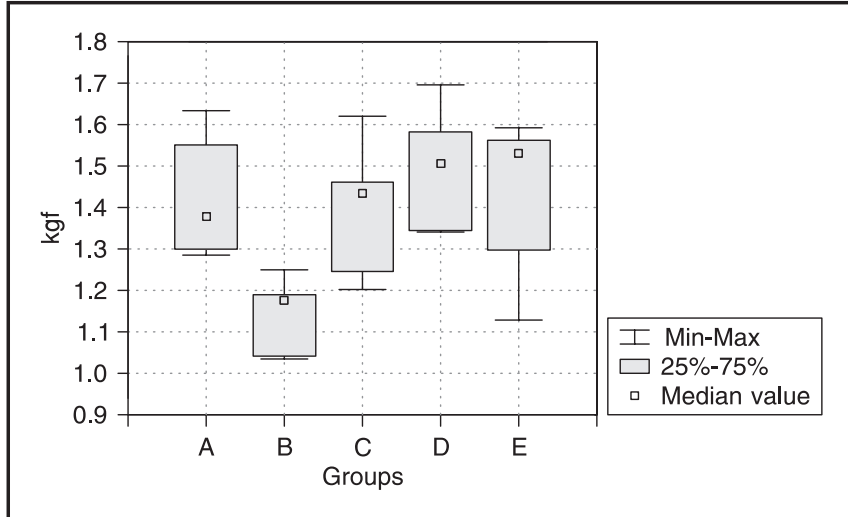

GRAPHIC 1 - Core retention: mean values in a box-and-whisker plot diagram.

$\mathrm{D}$ and $\mathrm{E}$ is favorable to the retention of the core, which corroborates the results of other studies $^{3,15,16,24}$. The surface treatments performed in Groups C and D transformed plain carbon posts into good clinical alternatives to serrated posts because of their mechanical properties. Comparing the results obtained by LOVE; PURTON ${ }^{15}$ (1996) with the results of this study, it is possible to observe that the same kind of failure that occurred in Groups C, D and E was found, i.e., fracture of the core in all samples, which reflects the tension induced in the core material, depending on the shape of the head. The alteration produced in Group D is inconvenient for clinical purposes, but it is important to suggest that the manufacturers keep the posts plain in the root portion and alter the coronal end for greater retention.

From the clinical standpoint, non-catastrophic failures (100\% in Group B and 20\% in Group A) are not only failures of the restoration - they may also cause great damage to the tooth because of the time interval between the failure and its detection, allowing the development of microleakage and root caries. The catastrophic failures in Groups C, D and $\mathrm{E}^{11}$ are clinical failures of the restorations and demand their immediate substitution.

The use of composite resins as core materials is more popular nowadays because they are easy to handle and can be immediately prepared ${ }^{2}$. However, many factors can contribute to the integrity of the interface between the post and the core. The possible effect of thermal stress in composite resins is otherwise minimized because there is less transmission of heat under a crown than it would be expected in a direct composite restoration, but further studies are necessary. CHANG; MILLSTEIN $^{3}$ (1993) considered posts and cores less reli-

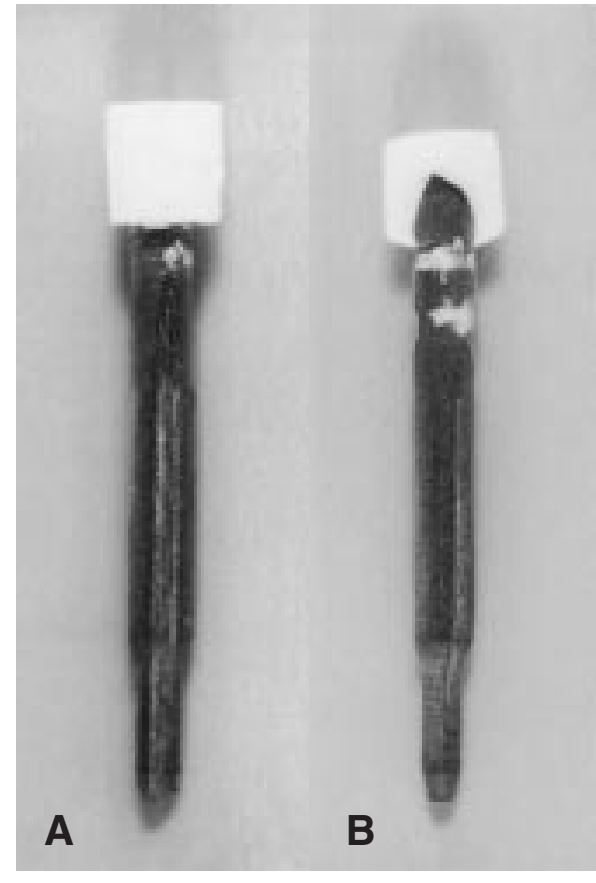

FIGURE 4 - A: dislodgment of the resin core after tension load; B: fracture of the resin core after tension load.

able when compared with cast posts because of the greater number of interfaces. DURET et al. ${ }^{6}$ (1990) stated that the different moduli of elasticity of the post material and the core material can affect the bonding resistance. The chemical compatibility between the composite resin of the core and the epoxy matrix of carbon posts would lead to a better interface; however, the heat treatment performed during the fabrication of carbon posts can play an important role in this adhesion, resulting in a worse interface.

The mechanical tension between posts and radicular dentin is also related to the type of core material $^{15,16,32}$. Tension is greater for cast posts when compared with posts and composite cores, according to YAMAN; THORSTEINSSON ${ }^{32}$ (1992). Failures related to the use of composite resins as core materials are mainly related to their low modulus of elasticity ${ }^{29}$. KOVARIK et al. ${ }^{14}$ (1992) pointed out that failures with composite resin cores occur at the interface, stressing the importance of a good interface; a good quality interface should be expected with chemical and mechanical adhesion.

\section{CONCLUSIONS}

- The surface treatments applied to plain carbon posts - sandblasting (Group A), diamond burs for laminated veneers (Group C) and alteration of 
QUINTAS, A. F.; BOTTINO, M. A.; NEISSER, M. P.; ARAÚJO, M. A. J. de. Effect of the surface treatment of plain carbon fiber posts on the retention of the composite core: an in vitro evaluation. Pesqui Odontol Bras, v. 15, n. 1, p. 64-69, jan./mar. 2001.

the form of the head (Group D) - improved the retention to the core, producing values comparable to those of serrated posts, with no statistically significant difference.

- The surface treatment recommended by the manufacturer - with medium diamond burs (Group B) - produced the least retention to the core, which was statistically significant in relation to the other Groups and contraindicated this alteration for clinical purposes.

QUINTAS, A. F.; BOTTINO, M. A.; NEISSER, M. P.; ARAÚJO, M. A. J. de. Efeito do tratamento superficial de pinos de fibra de carbono lisos na retenção da resina de preenchimento: uma avaliação in vitro. Pesqui Odontol Bras, v. 15, n. 1, p. 64-69, jan./mar. 2001.

Foi avaliado o possível efeito de tratamentos superficiais em pinos de fibra de carbono lisos, quando comparados aos pinos serrilhados, na retenção à resina composta empregada na confecção de núcleos de preenchimento. Foram utilizados cinqüenta pinos de fibra de carbono, divididos em cinco grupos: os quatro primeiros grupos eram constituídos por pinos do tipo liso, cujas superficies foram tratadas, e o último grupo por dez pinos do tipo serrilhado. Foram desenvolvidas matrizes de resina acrílica com um leito ajustado para conter o pino, com um alargamento na porção coronária para posterior preenchimento com resina composta. Após o tratamento superficial, todos os pinos receberam camadas de "primer", foram secos e então ajustados à matriz de resina, colocando-se a resina composta autopolimerizável na porção coronária para um núcleo de preenchimento de $3 \mathrm{~mm}$. As amostras foram submetidas a termociclagem e armazenadas em água destilada por uma semana. Os espécimes foram testados por meio de ensaios mecânicos de tração, à velocidade de $0,5 \mathrm{~mm} / \mathrm{min}$, até o deslocamento do conjunto ou a fratura da resina do núcleo. As conclusões foram as seguintes: a) o tratamento superficial nos grupos tratados por meio de jateamento (Grupo A), pontas diamantadas marcadoras de profundidade para facetas laminadas (Grupo C) e alteração da morfologia da extremidade coronária (Grupo D) conferiu aos pinos lisos valores de retenção comparáveis aos dos pinos serrilhados (Grupo E) nos ensaios de tração, porém sem diferença estatisticamente significativa entre estes grupos; b) os pinos tratados por meio de pontas diamantadas de granulação média (Grupo B) obtiveram valores de retenção menores que os demais grupos.

UNITERMOS: Pinos dentários pré-fabricados; Resina composta; Retenção.

\section{BIBLIOGRAPHIC REFERENCES}

1. ABOU-RASS, M.; DONOVAN, T. E. The restoration of endodontically treated teeth. J Calif Dent Assoc, v. 21, n. 12, p. 61-67, Dec. 1993.

2. BOTTINO, M. A.; QUINTAS, A. F.; MIYASHITA, E.; GIANNINI, V. Estética em reabilitação oral "metal-free". Artes Médicas, 2001. p. 67-123.

3. CHANG, W. C.; MILLSTEIN, P. L. Effect of the design of prefabricated post heads on core materials. J Prosthet Dent, v. 69, n. 5, p. 475-482, May 1993.

4. DEUTSCH, A. S.; MUSIKANT, B. L.; CAVALlARI, J.; LEPLEY, J. B. Prefabricated dowels: a literature review. J Prosthet Dent, v. 49, n. 4, p. 498-503, Apr. 1983.

5. DURET, B.; REYNAUD, M.; DURET, F. Un noveau concept de reconstituition corono-radiculaire: le composipost (1). Chir Dent Fr, v. 60, n. 540, p. 131-141, Nov. 1990.

6. DURET, B.; REYNAUD, M.; DURET, F. Un noveau concept de reconstituition corono-radiculaire: le composipost (2). Chir Dent Fr, v. 60, n. 542, p. 69-77, Dec. 1990.

7. FREEDMAN, G. The carbon fiber post: metal-free, post-endodontic rehabilitation. Oral Health, v. 86, n. 2, p. 23-30, Feb. 1996.

8. FREDRIKSSON, M.; ASTBÄCK, J.; PAMENIUS, M.; ARVIDSON, K. A retrospective study of 236 patients with teeth restored by carbon fiber-reinforced epoxy resin posts. J Prosthet Dent, v. 80, n. 2, p. 151-157, Aug. 1998.

9. FREILICH, M. A.; MEIERS, J. C.; DUNCAN, J. P.;
GOLDBERG, A. J. Fiber-reinforced composites in clinical dentistry. Quintessence, 2000.

10. HORNBROOK, D. S.; HASTINGS, J. H. Use of a bondable reinforcement fiber for post and core build-up in an endodontically treated tooth: maximizing strengths and aesthetics. Pract Periodontics Aesthet Dent, v. 7, n. 5, p. 33-42, July 1995.

11. HUYSMANS, M. C. D. N. J. M.; PETERS, M. C. R. B.; VAN DER VARST, P. G. T.; PLASSCHAERT, A. J. M. Failure behavior of fatigue-tested posts and cores. Int Endod J, v. 26, n. 5, p. 294-300, Sept. 1993.

12. ISIDOR, F.; ÖDMAN, P.; BRÖNDUM, K. Intermittent loading of teeth restored using prefabricated carbon fiber posts. Int J Prosthodont, v. 9, n. 2, p. 131-136, 1996.

13. KING, P. A.; SETCHELL, D. J. An in vitro evaluation of a prototype CFRC prefabricated post developed for the restoration of pulpless tooth. J Oral Rehabil, v. 17, p. 599-609, 1990.

14. KOVARIK, R. E.; BREEDING, L. C.; CAUGHMAN, W. F. Fatigue life of three core materials under simulated chewing conditions. J Prosthet Dent, v. 68, n. 4, p. 584-90, Oct. 1992.

15. LOVE, R. M.; PURTON, D. G. The effect of serration on carbon fiber posts retention within the root canal, core retention, and post rigidity. Int J Prosthodont, v. 9, n. 5, p. 484-488, 1996.

16. MANNING, K. E.; YU, D. C.; YU, H. C.; KWAN, E. W. Factors to consider for predictable post and core build-ups of endodontically treated teeth. Part I: basic theoretical 
QUINTAS, A. F.; BOTTINO, M. A.; NEISSER, M. P.; ARAÚJO, M. A. J. de. Effect of the surface treatment of plain carbon fiber posts on the retention of the composite core: an in vitro evaluation. Pesqui Odontol Bras, v. 15, n. 1, p. 64-69, jan./mar. 2001.

concepts. J Can Dent Assoc, v. 61, n. 8, p. 685-695, Aug. 1995.

17. MANNING, K. E.; YU, D. C.; YU, H. C.; KWAN, E. W. Factors to consider for predictable post and core build-ups of endodontically treated teeth. Part II: clinical applications of basic concepts. J Can Dent Assoc, v. 61, n. 8, p. 696-707, Aug. 1995.

18. MARTINEZ-INSUA, A.; DA SILVA, L.; RILO, B.; SANTANA, $\mathrm{U}$. Comparison of the fracture resistances of pulpless teeth restored with a cast post and core or carbon-fiber post with a composite core. J Prosthet Dent, v. 80, n. 5, p. 527-532, Nov. 1998.

19. MORGANO, S. M.; HASHEM, A. F.; FOTOOHI, K.; ROSE, L. A nationwide survey of contemporary philosophies and techniques of restoring endodontically treated teeth. $\mathbf{J}$ Prosthet Dent, v. 72, n. 3, p. 259-267, Sept. 1994.

20. MORGANO, S. M.; MILOT, P. Clinical success of cast metal posts and cores. J Prosthet Dent, v. 70, n. 1, p. 11-6, July 1993.

21. NATHANSON, D.; ASHAYERI, N. New aspects of restoring the endodontically treated tooth. Alpha Omegan, v. 83, n. 4, p. 76-80, 1990.

22. PLASMANS, P. J. J. M.; WELLE, P. R.; VRIJHOEF, B. S. In vitro resistance of composite resin dowel and cores. $\mathbf{J}$ Endod, v. 14, n. 6, p. 300-304, June 1988.

23. PURTON, D. G.; LOVE, R. M. Rigidity and retention of carbon fiber versus stainless steel root canal posts. Int Endod J, v. 29, n. 4, p. 262-265, July 1996.

24. PURTON, D. G.; PAYNE, J. A. Comparison of carbon fiber and stainless steel root canal posts. Quintessence Int, v. 27, n. 2, p. 93-97, 1996.

25. SCHETRITT, A.; STEFFENSEN, B. Diagnosis and management of vertical root fractures. J Can Dent Assoc, v. 61, n. 7, p. 607-613, July 1995.

26. SCURRIA, M. S.; SHUGARS, D. A.; HAYDEN, W. J.; FELTON, D. A. General dentists patterns of restoring endodontically treated teeth. J Am Dent Assoc, v. 126, n. 6, p. 775-779, June 1995.

27. SIDOLI, G. E.; KING, P. A.; SETCHELL, D. J. An in vitro evaluation of a carbon fiber-based post and core system. J Prosthet Dent, v. 78, n. 1, p. 5-9, July 1997.

28. SORENSEN, J. A.; MARTINOFF, J. T. Intracoronal reinforcement and coronal coverage: a study of endodontically treated teeth. J Prosthet Dent, v. 51, n. 6, p. 780-784, June 1984.

29. TORBJÖRNER, A.; KARLSSON, S.; ÖDMAN, P. A. Survival rate and failure characteristics for two post designs. $\mathbf{J}$ Prosthet Dent, v. 73, n. 5, p. 439-444, May 1995.

30. TORBJÖRNER, A.; KARLSSON, S.; SYVERUD, M.; HENSTEN-PETTERSEN, A. Carbon fiber reinforced root canal posts. Eur J Oral Sci, v. 104, p. 605-611, 1996.

31. VIRE, D. E. Failure of endodontically treated teeth: classification and evaluation. J Endod, v. 17, n. 7, p. 338-342, July 1991.

32. YAMAN, P.; THORSTEINSSON, T. S. Effect of core materials on stress distribution of posts. J Prosthet Dent, v. 68, n. 3, p. 416-420, Sept. 1992.

Recebido para publicação em 06/01/00 Enviado para reformulação em 14/11/00 Aceito para publicação em 06/12/00 